\title{
The Settlement Practice of Environmental Disputes Involving Foreign Investors in Vietnam - the Two Sides of the FDI Coin
}

\author{
Tran Viet Dung* and Ngo Nguyen Thao Vy**
}

The last two decades have been an extraordinary period for Vietnam. The country has undergone dramatic economic development from a centrally planned economy to a "socialist-oriented market economy"1 under the umbrella of the Doi Moi (Renovation) Policy. Significantly, Vietnam has openly recognized the importance of international economic cooperation. ${ }^{2}$ Attracting foreign direct investment ("F DI") has been a key part of Vietnam's external economic affairs. The Government of Vietnam has made tremendous efforts to develop the business and investment climate, and by recognizing that the FDI sector is an integral part of the economy - essential to restructuring the economy and raising national competitiveness. ${ }^{3}$

Vietnam has offered certain forms of legal protection to foreign investors, such as most-favored-nation treatment, national treatment, equitable

* Associate Professor, Dean of the International Law Faculty, Ho Chi Minh City University of Law, Senior Consultant of Victory LLC.

** Law Lecturer, Faculty of International Law, Ho Chi Minh City University of Law.

The research reflected in this article has benefited from funding through the European Union's Horizon 2020 research and innovation programme under the Marie SkłodowskaCurie grant agreement No. 734712 .

1 Pursuant to Political Report of the Vietnamese Communist Party Central Committee at Party Congress XII, the Vietnam's "socialist-oriented market economy" is an economy operating fully and synchronously according to the rules of a market economy while ensuring the socialist orientation suitable to each period of national development. It is a modern and internationally integrated market economy which is administered by a law-ruled socialist state [nhà nước pháp quyền xã hội chủ nghĩa] and led by the Communist Party of Vietnam toward the goal of a rich people and a developed, democratic, equal and civilized country. The term is first used in the 1992 Vietnamese Constitution to characterize the new model of economic structure in the era of Doi Moi.

2 Viet Dung Tran, Anti-Dumping Policy and law of Vietnam: A Critical AnalySis from Integration and Competition Policy Perspectives 55 (2011).

3 World Bank, Vietnam Development Report 2006 - Business (2005), http:/siter esources.worldbank.org/INTVIETNAM/Resources/vdr_20o6_english.pdf. 
treatment, protection and security, provision on compensation for losses incurred by foreign investors as a result of expropriation. These protections are cemented as the country's international obligations under bilateral investment treaties ("ВІт") ${ }^{4}$ and regional trade agreements. ${ }^{5}$ The participation in the multilateral and regional economic arrangement indicates that Vietnam is concerned to protect also the interests of foreign investor in its territory.

It should be noted that FDI inflows have seen a steady and strong increase after Vietnam's successful accession to the World Trade Organization ("WTO"). The period of 2010-2015 showed the establishment of Vietnam as a major manufacturing hub in the region, with the large majority of FDI flowing into the manufacturing and processing sector. ${ }^{6}$ It is recognized that foreign investment projects have played a very important role, not only in providing investment capital but also in stimulating export activities, as well as introducing new labor and management skills, transferring technologies and generating job opportunities in Vietnam.

However, FDI also contributes to various environmental problems and challenges to Vietnam. According to the survey provided in the "Mitigation of Environmental Impacts Related to FDI in Vietnam" workshop held by the Central Institute for Economic Management (“CIEM") and the EU-MUTRAP Project in June 2016, nearly 67 percent of FDI enterprises operating in Vietnam are export manufacturing companies with low value-added products, backward energy-consuming technologies and high emissions to the environment. ${ }^{7} \mathrm{Re}-$ garding environmental impacts from operation activities, while most of the FDI companies are aware of their obligation to comply with the environment

4 Vietnam has executed 65 BITs since 1992, amongst them 12 BITs have not been in force and three BITs were terminated (the BITs with Indonesia (1994), Korea (1993) and Finland (1996) were replaced by new BITs). UNCTAD, International Investment Agreements Navigator: Viet Nam, http://investmentpolicyhub.unctad.org/IIA/CountryBits/229\#iiaInnerMenu (last visited Mar. 10, 2017) [hereinafter UNCTAD].

5 Id. Vietnam has executed eight Regional Trade Agreements, including seven free trade agreements (FTA) and the ASEAN Comprehensive Investment Agreement (ACIA), which is a component of the legal framework of the ASEAN Economic Community.

6 Dubai Exps., Vietnam - Economic Overview \& Trade Analysis 7 (2017), http://www .dedc.gov.ae/StudiesAndResearchDocument/MTR-23092017-VIETNAM-Q3.pdf.

7 Central Institute for Economic Management, Proceedings of the Workshop on the Mitigation of Environmental Impacts Related to FDI in Vietnam (June 15, 2016) (transcript available in the Central Institute of Economic Management). 
regulations that requires them to prepare an Environmental Impact Assessment Report ("EIAR") upon application for approval of the investment project, most of them choose to disregard or not fully comply with environment protection requirements by the law.

Such non-compliance leads to the increasing rise of environment disputes on a national scale. According to the year 2000 report of the Inspectorate of the Ministry of Science, Technology and Environment on the results of inspection, from 1994 to 2000 , there were $3,25^{2}$ cases of breach of environment protection laws, of which the breaching entities in 1,515 cases, accounting for 46.57 percent of the total number of breaches, had the responsibility to compensate for damage caused to organisations and individuals. While data concerning the number of environment disputes in Vietnam is not officially collected or widely published since then, most of the disputes related to the violation committed by FDI companies through their operation activities and are on the increasing trend. The major environmental disputes caused by FDI projects arose in the period from 2008 to 2016, which included among others Vedan Vietnam Enterprise Corporation Limited's (Vedan Vietnam) committed pollution acts in Thi Vai River in 2008 and Formosa Steel's toxic waste water alleged causing massive fish deaths in Ha Tinh province in April 2016. Therefore, it is of essential to have an insight into the legal framework on foreign investment, environmental protection as well as the practice of environmental dispute settlement in Vietnam in order to find solutions to meet the urgent needs of the society.

International Instruments to Regulate FDI in Vietnam

It is important to understand the international and national instruments regulating FDI in Vietnam, in order to assess the issues of environmental protection related to FDI and settlement of environmental disputes involving foreign investors in Vietnam. The implementation of international obligations of Vietnam on the protection of foreign investments in the light of national environmental policy should be highlighted, as it would ensure the sustainability of economic growth for the state.

Vietnam, like most developing countries, has been regarded the international investment agreements ("IIAs") as a vehicle to attract FDI. By concluding IIAs, the Vietnamese government seeks to bind itself with international obligations to protect FDI as well as to make the regulatory framework for FDI more transparent, stable and predictable - and thereby more attractive to foreign investors. The government understands that the obligations embedded in 
IIAs would constrain its sovereignty by specifically limit their ability to take necessary legislative and administrative actions to advance and protect their national interests. ${ }^{8}$

In the 1990s, Vietnam signed the first BITs with important trading partners, such as Thailand (1991), Singapore (1992), China (1992), Australia (1991), Korea (1993), France (1992). By execution of the BITs, Vietnam sought to demonstrate to the international community about its new open door policy towards FDI and thereby reduce political risks for foreign investors. ${ }^{9}$ The BITs of Vietnam were designed to regulate following issues: (i) the definition and foreign investors and their investments, (ii) fair and equitable treatment towards FDI, (iii) national treatment - foreign investors must not be treated less favourably than their domestic counterparts, (iv) most-favoured-nation treatment, (v) compensation in the event of expropriation, (vi) guarantees of the free transfer and repatriation of capital and profits, and (vii) method of settling investment dispute. By granting foreign investors access to international arbitration under the BITs, the Vietnamese government demonstrated a strong commitment to honour its obligations, which should further enhance investor confidence.

As a member of the Association of Southeast Asian Nations ("ASEAN"), Vietnam signed the Framework Agreement on the ASEAN Investment Area (AIA) on October 7, 1998 and ASEAN Comprehensive Investment Agreement ("ACIA") on 29 February 2009. The latter aims to make ASEAN a competitive, conducive and liberal investment area. After accession to the ASEAN and ASEAN Free Trade Area in 1995, Vietnam has become a party to 5 FTAs between ASEAN and China, Japan, South Korea, India, Australia-New Zealand. ${ }^{10}$ These regional trade treaties also make reference to the foreign investment protection provisions. The participation of Vietnam in these regional trade arrangements indicates the Vietnamese government's commitment toward deep economic integration ${ }^{11}$ and development of a strong FDI protection system in accordance with international law. The development of IIAS

8 Karl P. Sauvant \& Lisa E. Sachs, The Effect of Treaties on Foreign Direct Investment: Bilateral Investment Treaties, Double taxation Treaties, AND InVESTMENT Flows 67 (2009).

9 Jeswald W. Salacuse \& Nicholas P. Sullivan, Do BITs Really Work?: An Evaluation of Bilateral Investment Treaties and Their Grand Bargain, 46 Harvard International LaW JOURNAL 67 (2005).

10 The ASEAN-China FTA was concluded in 2009 (effective in 2010); the ASEAN-Korea FTA was concluded in 2009 (effective in 2010); the ASEAN-Australia-New Zealand FTA was concluded in 2009 (effective in 2010); and the ASEAN-Japan FTA was concluded in 2008 (effective in 2008). See also UNCTAD, supra note 4.

See Tran, supra note 2 , at $57-59$. 
network together with liberalisation policy have facilitated the FDI inflows in Vietnam. In 2016, foreign investments climbed to US $\$ 24.4$ billion, indicating a nine percent growth compared to $2015 \cdot{ }^{12}$ Of these, US $\$ 15.1$ billion flew to 2,556 newly registered projects, 1,225 existing projects added a total of US $\$ 5.76$ billion to their capital, and foreign investors purchased stakes in 2,547 companies for a total value exceeding US $\$ 3.4$ billion. ${ }^{13}$

To date, Vietnam is a party to over 85 IIAs. ${ }^{14}$ In general, these IIAs acknowledge the significance of investment relation promotion and pursue objectives regarding the protection of investments, by legalizing a clear statement of principles to protect foreign investments. However, only very few of them cover the issue of protection of human health and the environment. Accordingly, only two out of 65 BITs concluded during 1990 to 2016 contain provisions referring to the environment protection together with the purpose to enhance the investment cooperation, which are the Japan - Vietnam BIT and the Finland - Vietnam BIT.

The Japan - Vietnam вIт (2004) recognizes that the investment objectives "can be achieved without relaxing health, safety and environmental measures of general application." ${ }^{15}$ Article 21 of the BIT also asserts that:

The Contracting Parties recognize that it is inappropriate to encourage investment by investors of the other Contracting Party by relaxing environmental measures. To this effect, each Contracting Party should not waive or otherwise derogate from such environmental measures as an encouragement for the establishment, acquisition or expansion in its Area of investments by investors of the other Contracting Party. ${ }^{16}$

Moreover, the Japan-Vietnam BIт also emphasizes the "public purpose" as the basis of exercising the State's police powers, in spite of there being no detailed clarification of the term. This provision aims to help the investment hosting

12 General Statistics Office Report (2016), https://www.gso.gov.vn/Default_en.aspx?tabid=515 (last visited Oct. 10, 2017); see also Brief on Foreign Direct Investment in 2016, MINISTRY OF Planning \& InV., http://www.mpi.gov.vn/en/Pages/tinbai.aspx?idTin=35721 (last visited Oct. 10, 2017).

13 Brief on Foreign Direct Investment in 2016, supra note 12.

14 UNCTAD, supra note 4.

15 Agreement between Japan and the Socialist Republic of Viet Nam for the Liberalization, Promotion and Protection of Investment, Japan-Viet., Preamble, Nov. 14, 2003, https:// investmentpolicyhubold.unctad.org/Download/TreatyFile/1738.

$16 \quad I d$. art 21. 
state to carry out regulatory measures against the FDI that would serve the non-economic interest and welfare of the society.

Amongst 21 BITs with EU member states, only the Finland - Viet Nam BIT (2008) contains the reference to environmental issue in its Preamble ${ }^{17}$ and the exception for expropriation regarding "public interest."18 Hence, it is expected that these 21 BITs will be replaced by the free trade agreement between the European Union and Viet Nam (EVFTA), which completed negotiation in 2015. The EVFTA unifies the objectives of the former BITs among the regional countries with Vietnam by providing that "each Party retains the right to adopt, maintain and enforce measures necessary to pursue legitimate policy objectives such as the protection of society, the environment and public health" in both the Preamble and provision regarding investment and regulatory measures. ${ }^{19}$ Significantly, the EVFTA has a separate chapter on Trade and Sustainable Development, reaffirming the parties' commitment to pursue sustainable development and providing a cooperative approach based on common values and interests in addressing issues concerning trade and environment. ${ }^{20}$

To prepare for the ASEAN Economic Community, Vietnam together with other ASEAN member states have signed the ACIA in 2012, which replaced the AIA of 1998. Hence, the ACIA does not replace the existing 28 BITs conclude amongst and between ASEAN member countries (ASEAN BITS). ${ }^{21}$ It should be noted that while the ASEAN BITs do not include environment preservation

17 Agreement between the Government of the Republic of Finland and the Government of the Socialist Republic of Viet Nam on the Promotion and Protection of Investments, Fin.Viet., Feb. 21, 2008, 2598 U.N.T.S. 189 (entered into force June 4, 2009) [hereinafter FinlandViet Nam BIT] ("[The parties] [a]greeing that these objectives can be achieved without relaxing health, safety and environmental measures of general application.").

18 See id. at 194.

19 Free Trade Agreement Between the European Union and the Socialist Republic of Vietnam, EU-Viet., Preamble \& art. 13bis, July 2018, Eur. Commission.

20 See id. art. 9.

21 Viet Dung Tran, Thực thi Hiệp định Đầu tư toàn diện ASEAN: Những vấn đề từ sự chồng chéo trong các cam kết bảo hộ đầu tư nước ngoài của Việt Nam [Implementation of ASEAN Comprehensive Investment Agreement: The Issues from the Overlapping of the Investment Protection Commitments of Vietnam], 4 Journal of Legal Studies 45 (2017); see also Junianto James Losari, Comprehensive or BIT by BIT: The ACIA and Indonesia's BITs, 6 ASIAN Journal OF INTERNATIONAL LAW 15 (2016). 
objectives, the ACIA regulates that the member states are entitled to design and apply measure(s) to protect legitimate public welfare objectives, such as public health, safety, and the environment. ${ }^{22}$ In other words, the ACIA permits the Vietnamese government to terminate the foreign investor's license and ban all of their business activities (the investors from ASEAN only), provided it can prove that the measure is non-discriminatory and necessary to protect public health and/or the environment. For FDI management, the ACIA's expropriation clause (with the Annex 2) is significant for the government, because the factors in determining whether an indirect expropriation occurs are stated explicitly. This will allow the government to design their measures accordingly. ${ }^{23}$

In the context of the international instrument governing FDI and environmental protection in Vietnam, it is necessary to note the role of wTO rules. The justification to engage the wTо in human rights and environmental protection can be deduced from the competency of the што in international trade which regulates not only international trade but also investment. Accordingly, Article $\mathrm{xx}(\mathrm{b})$ of GATT lays the groundwork for a human rights body within the wTO. Trade and human rights are linked within the wTO system as Article $\mathrm{xx}(\mathrm{b})$ and Article XX(g) GATT appears to permit WTO member countries to apply special trade sanctions to protect the human, animal health, and environment. ${ }^{24}$ The WTO can be expected to incorporate environmental standards into its mechanisms for regulating trade. Although, the primary objects of wTO regulations have always been products as defined by their physical characteristics. However, international trade regulation has recently been expanded to include process factors as well. ${ }^{25}$

22 ASEAN Comprehensive Investment Agreement Annex 2, ๆ 4, opened for signature Feb. 26, 2009, Ass'N Se. Asian NAtions, http://agreement.asean.org/search.html?q=Compr ehensive+Investment+Agreement+ (entered into force Feb. 24, 2012).

23 Losari, supra note 21.

24 Christiana Ochoa, Advancing the Language of Human Rights in a Global Economic Order: An Analysis of Discourse, 23 Boston College Third World LaW Journal 57, $65-83$ (2003); Sanford Gaines, The WTO's Reading of the GATT Article XX Chapeau: A Disguised Restriction on Environmental Measures, 22 University of PENNSYLVANIA Journal of International EConomic LAW 739, 739-806 (2001); Mike Meir, GATT, WTO, and the Environment: To What Extent Do GATT/WTO Rules Permit Member Nations to Protect the Environment When Doing So Adversely Affects Trade?, 8 Colorado Journal of InTERnational Environmental LaW and Policy 241 (1997).

25 The rules and regulations of the TBT and SPS agreements of the WTO can presumably create base for national measures for the purpose of protection of environment and/or human rights. Such a presumption of validity would help to prevent disputes or claims based on indirect discrimination or de facto expropriation. See Sol Picciotto, Rights, 
Overall, to date, most of the IIAs in which Vietnam is a member do not specify the interrelationship between the investment and environment, the sustainable development and reference to environmental aspects (except those mentioned above), as well as not clearly defining the term "public purpose" or "public interest" which is taken to account in case the State exercises its police power. Therefore, it is difficult for Vietnam, as host State, to acknowledge its rights regarding the environment protection purpose and the extent of such rights in case an environmental violation by the foreign investor arises. This leads to the risk that the government is put under pressure as it would be subject to claims by multinational corporations (MNC) through international arbitration based on indirect expropriation. Moreover, the vague and general provisions of IIAs do not ensure or encourage the compliance of the investor with environmental legal regulations in the stages of establishment and operation of an investment project. The current IIAs of Vietnam seem to tie the hands of the government in regard to FDI and environmental protection (by imposing high liabilities for the state upon conducting any action/measure against the FDI which might be tantamount to indirect expropriation).

\section{$3 \quad$ National Regulations on Foreign Investment and Environmental Protection}

Since the implementation of the Doi Moi Policy, the Vietnamese Government has recognized the significance of foreign investments as an important source for modernization of the economy and sustainable economic growth. To attract FDI, the government introduced the Foreign Investment Law (FIL) in 1987, which was regarded as the cornerstone of the 'opened door' policy for foreign capital in Vietnam.

The Constitution 1992 has recognized, for the first time, the development of a market economy with socialist orientation, the concept of private property and the right of individuals to conduct business activities. It expressly acknowledges foreign-owned capital as a legitimate sector of the economy, encouraging foreign investment and guaranteeing that assets of foreign investors will not be expropriated.

The National Assembly has further modified the FIL in 1996 and 2000 to improve the conditions for FDI, including the acknowledgment of the foreign investor's rights to open branches in Vietnam and assign interests in the

Responsibilities and Regulation of International Business, 42 Columbia Journal of Transnational LaW 131 (2003). 
foreign-owned enterprise to any parties. In 2005, the Law on Investment and Law on Enterprises were passed by the National Assembly to establish a common regime and unified ground for domestic and foreign investment in Vietnam, which makes it easier for foreign investors to invest and carry out business in the country. This legislative development on investment was influenced by the process of negotiation to access the wто. ${ }^{26}$ The law and regulations on investment should be harmonized with the TRIMs Agreement and other relevant agreements of WTO.

From 2007 to 2014, many regulations were issued, specifically mentioning the steps the Government has taken to improve the investment climate. It is worth noting that the regulations of the business sectors and sub-sectors that are conditionally open to FDI. In 2014, Vietnam has adopted a new Law on Investment (LOI 2014), which has taken effect as of July 1, 2015, and replaced the Law on Investment 2005, which deems to further update and strengthen the regulations of investment guarantees. Notably, regarding investment incentives in the event of changes in law, the LOI 2014 and its guiding regulations warrant that existing investors should be able to benefit from whichever provisions are most favorable during the remaining time in which the project is entitled to incentives. ${ }^{27}$ The LOI 2014 introduced many changes to open opportunities for foreign investors through new provisions on licensing procedures applicable to certain common investment forms, including investment along with setup of enterprise and investment in the form of capital contribution or sharing purchase in enterprises in Vietnam. It also reduced the number of conditional business lines for foreign investment. ${ }^{28}$

The LOI offers a chance to utilize a multi-layer ownership structure of subsidiaries in Vietnam to enter sectors where foreign investment is restricted. Accordingly, foreign-invested enterprises investing or acquiring equity in another Vietnamese enterprise (foreign-invested economic organizations FIEO) shall only be subject to the same conditions and investment procedures applicable to foreign investors if they can own at least $5^{1}$ percent of charter capital of the targeted enterprise. ${ }^{29}$

26 The Vietnam's commitments under the WTO influence the legal framework for foreign direct investment, regarding various issues such as the limitation on foreign ownership, corporate voting rights, trading rights, distinction of foreign invested company and domestic companies.

27 Law on InVestment [LOI] [Law No. 67/2014/QH13] art. 13, §§ 1-2 (Viet.).

28 Id. app. 4. The number of conditional business lines is 267 compared to 386 in the LOI 2005 .

29 Id. art. $23, \S 1$. 
Environmental protection in Vietnam, like most developing countries, was not the main focus of the policy makers. In fact, when economic growth was supposed to be the sole motive force for national development, the environment protection was not regarded as an important issue. Only at the turn of the century, when Vietnam has faced the danger of natural resource exhaustion, ecological imbalance, and repeated natural disasters, the environmental protection issue began to emerge as a social challenge. The promulgation of environmental law was one of the measures to surmount that challenge.

Although the 1993 Law on Environmental Protection and the subsequent 2006 Law on Environment Protection have created a legal framework for environmental protection, it revealed limitations that had to be addressed amid the country's efforts to boost industrialization, modernization, and Vietnam's global economic integration. To improve protection of the environment, the National Assembly of Vietnam adopted a new Law on Environmental Protection in 2014 ("LEP 2014"), which replaced the 2006 Law. The government has also introduced a number of guideline regulations for the purpose of the LEP's implementation. ${ }^{30}$

Ministry of Natural Resources and Environment (MONRE), the primary regulatory body responsible for protecting the environment, issued a number of circulars on the management of hazardous wastes and discarded materials in industrial parks. ${ }^{31}$ MONRE and its agencies shall collaborate with investment authorities to carry out state management of environmental protection by individuals and organizations operating in Vietnam.

30 Decree 19/2015/ND-CP, Gov'T (Feb. 14, 2015) (Viet.) (detailing and guiding implementation of a number of articles of the Law on Environmental Protection); Decree 179/2013/ ND-CP, Gov'T (Nov. 14, 2013) (Viet.) (on sanctioning administrative violations in environmental protection); Decree 18/2015/ND-CP, Gov'T (Feb. 14, 2015) (Viet.) (regulating strategic evaluation on environmental impact, commitment to environmental protection). See Circular 27/2015/TT-BTNMT, Ministry of NAt. Res. And Env't [MONRE] (May 29, 2015) (Viet.) (implementing strategic environmental assessments, environmental impact assessment and environmental protection undertakings); Circular 26/2015/TTBTNMT, MONRE (May 28, 2015) (Viet.) (regulating detailed environmental protection, simple environmental protection); Circular 41/2015/TT-BTNMT, MONRE (Sept. 9, 2015) (Viet.) (on environmental protection in import of scrap for use as raw production materials); Circular 25/2009/TT-BTNMT, MONRE (Nov. 16, 2009) (Viet.) (promulgating national technical regulations on the environment); Circular 32/2013/TT-BTNMT, MONRE (Oct. 25 , 2013) (Viet.) (promulgating national technical regulations on environment); Circular 47/2011/TT-BTNMT, MONRE (Dec. 28, 2011) (Viet.) (on national technical regulation on environment).

31 Circular 36/2015/TT-BTNMT, MONRE (June 30, 2015) (Viet.) (on management of hazardous wastes); Circular 35/2015/TT-BTNMT, MONRE (June 30, 2015) (Viet.) (providing for the environmental protection of economic zones, industrial parks, export processing zones and hi-tech parks). 
The current Vietnamese laws on environmental protection require investors (both foreign and domestic) to prepare either an Environmental Impact Assessment Report (EIAR) or an Environmental Protection Plan ("EPP") for their projects, depending on the importance and level of environmental impact of the project. An EIAR must be submitted to the appropriate authority for appraisal, while an EPP only needs to be registered. Under Article 19.2 of the LEP 2014, an EIAR must be prepared concurrently with the feasibility study of a project. Depending on the nature of each project, the appropriate authority shall appraise an EIAR (such as the MONRE, or a government agency, or provincial-level people's committee). Meanwhile, the EPP is registered with the district-level people's committee. That body, when necessary, may authorize commune-level people's committees to issue a certificate of registration before the investor may proceed with the activity.

As the EIAR is one of the most important documents of the whole investment project dossier, the LEP 2014 lists out certain types of investment projects that require the preparation of such report. ${ }^{32}$ Decisions on the approval of EIAR shall serve as a basis for competent authorities to: (i) decide on investment in projects; (ii) grant or modify licenses for mineral exploration projects; (iii) approve exploration and field development plans for oil and gas exploration and exploitation projects; (iv) grant or modify construction permits for projects having construction work items subject to construction licensing. ${ }^{33}$ After getting the EIAR appraised, a list of post-EIAR tasks are required for the investors, including the newly-prescribed duty to prepare the Environmental Supervision Report (ESR). ${ }^{34}$ The specification of such provision is vested on the authority of the Department of Resources and Environment ("DORE"). ${ }^{35}$

32 Law on Environmental Protection [LEP] art. 20, § 1 (Viet.).

The EIAR preparation requirement applies to nationally important projects, telecommunications, construction projects, industrial zones, many light and heavy manufacturing facilities, most mining projects and large-scale tourism and entertainment projects. Only the investor of the project not operated within 24 months or changed the location shall re-prepare the EIAR. In addition, when projects that change the scale, capacity, and technology resulting in the increase of negative impacts on the environment, the Government regulates the projects in detail. See also Một sốvấn đề về dự thảo Luật Bảo vệ môi trường sủa đổi [Some Issues Regarding the Revised LEP], INST. FOR LE GIS. REs. (Feb. 19, 2014), http:// vnclp.gov.vn/ct/cms/tintuc/Lists/cacduanluat/view_detail.aspx?ItemID=212.

33 LEP art. 25 (Viet.).

34 Decree No. 18/2015/ND-CP, Gov'T art. 16 (Feb. 14, 2015) (Viet.) (on environmental protection planning, strategic environmental assessment, environmental impact assessment and environmental protection plans).

35 Official Correspondence No. 3105/TNMT-QLMT, Ho Chi Minh City Department of Resources and Environment (Apr. 18, 2008) (details of the ESR content); Public Report No. 4228/CCBVMT-KS (while the relevant law and decrees remain unclear about the 
Despite the significance of such reports, there is no legal provision prescribing the standards or methods used for the preparation of EIAR and ESR to ensure their transparency and quality. In our observation, this is due to the impossibility of establishing a set of unified technical standards or methods applicable to various type of projects, as well as the desire of the legislator to create a flexible legal framework for the attraction of foreign investors.

Regarding the EPP, as a new concept and definition replacing the Environmental Protection Commitment under the LEP 2014, it is a token of the noticeable effort of the Government of Vietnam to create a flexible administrative legal framework on environmental protection. ${ }^{36}$ The EPP covers location, form, and scale of the establishment as well as the energy used and types of waste produced. They must also include an undertaking to minimize and treat waste and comply with environmental laws. A certificate showing registration of the EPP is required before manufacturing or other business activities may commence. As the EPP does not need to be reviewed and appraised by the governmental agencies, such flexibility encourages self-evaluation by the business community regarding environment protection activities. Moreover, such plan is seen as proof of legal compliance in the administration's point of view. Therefore, the new regulation of LEP 2014 ensures that the investors fully acknowledge their industrial impacts to the environment, serving the purpose of administration well and reducing the cost of compliance efficiently. It is believed that together with the current flexible mechanism of assessment, the EPP and EIA will offer favorable treatment for the investor while still ensuring the environment protection in Vietnam.

Overall, it is observed that during the last decades, Vietnam is determined to develop a comprehensive and updated national legal framework on FDI and environmental protection. The relevant laws and regulations are designed to support and facilitate investment, but are also concerned about environmental protection. In the area of environmental protection, the flexibility and

frequency of ESR submission, this report provides that project owners in Binh Duong Province are obliged to prepare the ESR quarterly and submit to the competent authority the whole annual collection of such report at the beginning of the following year. Meanwhile, project owners in other provinces and cities are required to do such task once in six months). See also Official Correspondence No. 4228/CCBVMT-KS (supplementing the Decision No. 63/2012/QD-UBND, People's Committee of Binh Duong Province (Dec. 18, 2012) (on guiding the preparation of environment supervision report for local enterprises)).

36 Some opinions oppose that the EPC cannot be replaced by the EPP and should be maintained in parallel, as each provision has different nature and applies in different stages of the investment project. Nevertheless, the majority of the Drafting Committee agrees that the EPP reflects the environment protection awareness and responsibilities of the business entities through their actions, administered by the competent authority. 
low standard of environmental protection required by the LEP seems to help foreign investors to save business performance expenses. It should be noted that in most cases, investors want to optimize production costs by extending the life cycle of the technology which has been banned in the investor's home country while it is acceptable in such developing countries thirsting for investment such as Vietnam. Thus, loosely-designed legal regulations on environmental assessment and inefficient environmental enforcement system in Vietnam is one of decisive factors attracting foreign investment. ${ }^{37}$ According to Dinh Duc Truong, nearly 20 percent of the FDI corporates reported that they can save up to 10 percent environment protection costs in comparison to that of their home countries, 68 percent admit that they can save from 10-50 percent and 12 percent of them believe that the costs can be reduced to more than 50 percent. ${ }^{38}$ Moreover, with low environment protection costs, taxes and fees, 68 percent of FDI companies expect to save 10-50 percent of the costs while operating in Vietnam, which is an ideal vision the investors want to obtain once their investment projects are launched. ${ }^{39}$ With such new regulations, Vietnam tries to define itself as an "apple of the investor's eyes."

However, such FDI-favoured approach in the legal framework also produces side-effects relating to the compliance of foreign investors with their environment protection duties. It is reported that more than $5^{1}$ percent of the investors participating in the research by CIEM in 2015 admited their projects do not fully observe the environment protection requirements and the operation of the factory may cause negative impacts to the environment. ${ }^{40}$ The reports of the Environmental Inspectorate Department of the Ministry of Natural Resource and Environment ("MONRE") showed that from 2010 to 2015, there were 89 cases monetary fines charged against foreign companies for violating procedural and environment standard rules. However, it is also observed that administrative fines are relatively quite low and not substantial enough to urge strict compliance by the MNCs. ${ }^{41}$ Such non-compliance and lax regulations are the

37 Dinh Duc Truong, Quản lý môi trường tại các doanh nghiệp đầu tưnước ngoài (FDI) tại Việt Nam [Managing Environment Issues at the Foreign Invested Enterprises in Vietnam], $3^{1}$ VNU Journal OF SCIENCE 46 (2015).

$38 \quad I d$. at 48 .

39 Id.

40 Central Institute for Economic Management, supra note 7.

41 According to regulation of Decree No. 179, the administrative fine would range from VND 5,000,000 (approximately USD 240) to VND 180,000,000 (appromiximately USD 8,570). See Decree 179/2013/ND-CP ch. 2, § 1 (Nov. 14, 2013) (Viet.) (on the sanction of administrative violations in the domain of environmental protection).

Meanwhile in Singapore, according to the Environmental Public Health Act 1987, as amended by Act 16 of 2016, an offender shall be responsible for a penalty of $\$ 2,000$ in 
source of negative environmental impacts and potential environmental disputes. As one of many undesired consequences of such FDI, the one who suffers most are the people living in such polluted areas, especially when their legal rights and interests are not effectively protected.

\section{a Overview of Environmental Disputes Involving Investors in Vietnam}

There is no national, published survey on environmental disputes by government agencies in Vietnam in the last decade. ${ }^{42}$ However, according to private research, environmental disputes, especially those arising from the industrial performance, are currently in the trend of increasing in various complexity levels and scales. ${ }^{43}$ The Institute for Strategic Studies and Implementation of Industrial Policy of MONRE reported that in Ho Chi Minh City, Dong Nai, Thai Nguyen, Hung Yen and Da Nang, the environmental pollution in industrial areas had been discovered mostly by local peoples and recognized only when they put pressure on local authorities to investigate. ${ }^{44}$ Environmental disputes in Vietnam are happening on a large scale and rank second after land disputes in terms of seriousness, causing great damage to many stakeholders, especially

minimum or $\$ 20,000$ in maximum depending on the type of violation committed (yet taking into account the additional fine for a continuing offence). See Environmental Public Health Act, 1987 (Sing.). In Thailand, pursuant to the 1992 Enhancement and Conservation of National Environmental Quality Act, B.E. 2535, the penalty for failure to meet environmental standards is to one-year imprisonment and/or a fine of up to 100,000 bahts. See Enhancement and Conservation of National Environmental Quality Act, 1992 (Thai.).

42 The only thorough research regarding the environmental disputes and alternative dispute resolution means in Vietnam was conducted by the Institute of State and Law of the National Centre for Social Sciences and Humanities Vietnam for period 1990-200o. See Institute of Developing Economies, The Alternative Dispute Resolution in Vietnam, 20 Institute of Developing Economies Asian Law Series (2002), https://www.ide. go.jp/library/English/Publish/Download/Als/pdf/20.pdf.

43 Nguyen Trung Thang et al., Nghiên cứu, đề xuất cơ chế giải quyết tranh chấp môi trường ngoài tòa án ở Việt Nam [Examining and Proposing the Out-of-Court Environment Dispute Settlement Mechanism in Vietnam], Viet. EnV'T Admin. (July 31, 2015, 4:47 PM), http:// vea.gov.vn/vn/truyenthong/tapchimt/nctd42009/Pages/Nghiên-cứu,-đề-xuất-cơ-chếgiải-quyết-tranh-chấp-môi-trường-ngoài-tòa-án-ở-Việt-Nam.aspx.

44 Mai Chi, Difficulties in Handling Environmental Disputes, Viet. Env't Admin. (Sept. 11, 2013, 2:38 PM), http://vea.gov.vn/en/EnvirStatus/StateOfEnvironmentNews/Pages/ Difficulties-in-handling-environmental-disputes-.aspx. 
local communities. ${ }^{45}$ One of the main sources of the problem is FDI projects. Many large-scale investment projects invested by MNCs operate in pollutionintensive and hazardous industries that have products or processes that may harm the environment or negatively impact human health.

Nevertheless, the practice of environmental dispute settlement in Vietnam pose many shortcomings due to the lack of an effective legal framework, organization structure, and enforcement mechanism. First, it can be clearly seen that the nature of the LEP after many revisions is still administration-oriented, illustrated by the entrustment of dispute settlement only to governmental agencies. This is because of the implied recognition by the legislator that environmental disputes are distinct from any civil disputes, as they concern both private and public interests. ${ }^{46}$ According to Daniel Louis, environmental cases "are technically and legally complex, [and] have serious environmental concerns and contain public policy considerations." ${ }^{47}$ For instance, victims of environmental pollution themselves may not only pursue compensation for personal damage, but also may advocate restoration of their local environment. Therefore, in this case, the regulation of administrative oversight seems to be necessary, and the mediator's primary task is to help parties reach an agreement that meets their interests and comports with the law on environmental protection. ${ }^{48}$

Second, regarding the environmental dispute settlement mechanisms, the LEP adopts both judicial and out-of-court means. In particular, Article 161.3 of LEP 2014 specifies that the settlement of environmental disputes shall comply with regulations on settlement of non-contractual civil disputes and other relevant regulations of Vietnamese law. In particular, Article 161.3 of LEP 2014 specifies that the settlement of environmental disputes shall comply with regulations on settlement of non-contractual civil disputes and other relevant regulations of Vietnamese law. Furthermore, in order to provide further opportunities for disputing parties to effectively resolve their cases, the LEP 2014 also offers a mediation mechanism entrusted to the Commune Level People's

45 Proposals to Resolve Environmental Disputes, Talk Viet. (Aug. 16, 2013), https://www .talkvietnam.com/2013/08/proposals-to-resolve-environmental-disputes.

46 Douglas J. Amy, Environmental Dispute Resolution: The Promise and the Pitfalls, 11 Ecology Law Quarterly 1 (1983), in Environmental Policy in the $1990 \mathrm{~s} 211$ (Norman J. Vig \& Michael E. Kraft eds., 1990).

47 How ADR Can Enhance Environmental Negotiations, Alte Rnatives to the Hig H Cost Litig. (CPR Inst. For Dispute Resolution, New York, N.Y.), May 1998, at 65-78.

48 Matthew Taylor et al., Using Mediation in Canadian Environmental Tribunals: Opportunities and Best Practices, 22 Dal housie LaW Journal 51, 68 (1999). 
Committee for any environmental disputes arising in a local region. ${ }^{49} \mathrm{Howev}-$ er, there is no guideline for the People's Committee's mediation commission considering the nature of environmental disputes to find an appropriate approach to resolve the case. As a consequence, resolving environment disputes are understood by such commissions as resolving security disorder rather than resolving environmental conflicts. ${ }^{50}$

Third, the complexity of discharging the plaintiff's burden of proof in environmental cases also results in protracted and expensive legal proceedings with only a small chance of success. Although the local residents make demands about compensation for health problems as well as losses to their livelihood, it is difficult for the local People's Committees alone to assign blame, determine the victims and assess the cost of pollution. While the burden of proof does lie upon the plaintiff, the judge retains a general discretion to vary the distribution of the burden of proof in the requirements of justice in each case ${ }^{51}$ Nevertheless, in any circumstance, this principle still imposes a heavy duty for people who in the majority of cases originate from the socially and economically weak sectors of society and are lacking accessibility to evidence as well as technical knowledge of environment. ${ }^{52}$ The research of ISPONRE conducted amongst citizens in 3 environmental disputes in Hai Duong, Nghe An and Dong Nai provinces (which are the large industrialised cities in Vietnam) shows that there is only $43-62$ percent local peoples reporting their cases have been partially resolved. Especially, in Dong Nai, 70 percent of the peoples involved in the air pollution case with an FDI corporation claim that their case has not been resolved. Amongst " 7 legal cases claiming damages for pollution ... all submitted in the 2010-2012 period[,]. . only one ... case[] was settled while the other $[\mathrm{s}]$... remained pending at the time of survey."53 Regarding the dispute settlement result, in most of the resolved cases claiming for environmental damages, "the compensation amount is only equal to 20 to 30 percent of the actual damage value and does not take into account any potential

49 LEP art. 143(3)(d) (Viet.).

5o Nguyễn Trung Thắng et al., Nghiên cứu, đề xuất cơ chế giải quyết tranh chấp môi trường ngoài tòa án ở Việt Nam [Research and Propose Environmental Dispute Settlement Mechanism Outside Court in Vietnam], VIỆN CHIẾN LƯợC, CHÍNH SÁCH TÀI NGUYÊN VÀ MÔI TRƯờnG [Inst. of Strategy and Pol'y on Nat. Resources and Env'T], http:// isponre.gov.vn/home/dien-dan/1076-nghien-cu-xut-c-ch-gii-quyt-tranh-chp-moitrng-ngoai-toa-an-vit-nam (last visited Oct. 10, 2017).

$5^{1}$ LEP arts. $165^{-66}$ (Viet.).

$5^{2} \quad I d$. art. 166 (Viet.).

53 UNDP, Justice Index: Assessment of Distributive Justice and Equality From a Citizen-BASEd SURVEY IN 201235 (2013). 
damage." ${ }^{54}$ Thus, it is no surprise that $75^{-93}$ percent of the affected residents are not satisfied with the dispute settlement result.

Lastly, regarding the current environmental dispute settlement mechanism, the granting of such authority to the Commune Level People's Committee seems to be ineffective in practice as the mediation committee's establishment and settlement procedures are not specified in the law. Moreover, this agency does not have enough experts to deliver exact decisions in complicated environmental disputes. To resolve such conflicts, the Commune Level People's Committees usually have to seek the assistance from the local Department of Resources and Environment of Province or transfer the claim to another competent authority, leading to delays in procedures which may affect the statute of limitations in case the claimant later wants to file his case in court. As a consequence, it usually takes from 2 to 3 years to handle the environmental cases. ${ }^{55}$ Regarding administrative complaints, " $[t]$ he average time taken to address ... ranged from 17 to 27 months, depending on the type of individual or household enquiry," while the dispute settlement outcome does not always satisfy the stakeholders. ${ }^{56}$ Besides, entrusting the local government as authority to settle the dispute is not appropriate and objective, since such agency is also involved in granting investment approval for the FDI project and environmental certificate.

All of these abovementioned drawbacks can be illustrated by two typical infamous pollution disputes involving FDI investors which are the Vedan case in 2008 and Formosa case in 2016. The merits of those disputes mainly concern (1) social welfare, (2) requests for environmental pollution treatment and compensation, and (3) requests for state authorities' resolution of tax and business registration problems. To the extent of our research in this paper, we focus on the analysis of the first two issues, which both will be discussed in detail below.

\section{b Some Typical Environmental Disputes Involving FDI in Recent Decades}

I Vedan Vietnam Case

Vedan Vietnam case is one of the most significant environmental disputes in the recent history of Vietnam. The dispute involves Vedan Vietnam Co. Ltd.

54 Institute of Developing Economies, supra note 42, at 117.

55 Nguyễn et al., supra note 50 (stating $67-86$ percent of the affected stakeholders claim that it takes a great deal of time for the case to be handled).

56 Right to Live Free of Pollution Unprotected in Vietnam, Thanh Nien News (Oct. 4, 2013, 3:0o PM), http://www.thanhniennews.com/society/right-to-live-free-of-pollution-unpro tected-in-vietnam-1049.html. 
("Vedan"), a 100 percent owned Vedan International (Holdings) Limited, "[the] premier manufacturer of fermentation-based amino acids, [starch,] food additive and cassava starch-based products [in Asia]." "57 "[Vedan's] prominent reputation has been built on the quality manufacture of MSG." ${ }^{\text {58 }}$ Since 1993, it started the business operation in Vietnam with almost 2,000 employees. The company attained Iso 9001:2000 certification, and was proud of being awarded on several occasions by the Vietnamese government for the company's contribution to the economy. ${ }^{59}$

Such image of the company was seriously tarnished by the fact that in 2008, the company was caught at the very moment of illegal "discharging [of] untreated effluent directly into the Thi Vai River through secret underground pipes." 60 This activity was done largely at night and in a regular manner. "Government inspectors [concluded] that the company had been dumping 105 million liters of untreated liquid waste [per] month into the river for 14 years[,]" causing 2,700 hectares of land along the river to become severely damaged and 80-9o percent of water in the Thi Vai River (which runs nearly 8okm through HCM City, Dong Nai and Ba Ria-Vung Tau provinces) to become polluted by the illegal discharges. ${ }^{61}$

This case received high publicity in Vietnam[,] ... [followed by] a mass condemnation of the company. Farmers, NGOs, politicians, a local [C] atholic bishop, and even business partners such as BigC and Sai Gon Co.op denounced the company ... [and] refused to conduct commercial transactions [with Vedan Vietnam] until the due restitution is made. The Prime Minister... [also] demanded the closure of the factory and severe punishment of the offenders according to criminal law. ${ }^{62}$

57 Vedan Int'l (Holdings) Ltd., Annual Report 20177 (2017), http://www.vedaninternational.com/investor/ir2018/Report2018/E-2018041904.pdf.

$58 \quad$ Id.

59 Corporate Major Event, VEDAN INT'L, http://www.vedaninternational.com/aboutvedan/ milestones.htm.

6o Minh Quang, Vedan "giết" sông Thị Vải [Vedan "Kills" Thi Vai River], TuoiTre OnLine (Sept. 15, 2008, 07:25 AM), http://tuoitre.vn/vedan-giet-song-thi-vai-278294.htm.

61 Dong Nai, Old Habit: Infamous Polluter Vedan at it Again in Southern Vietnam, Thanн NiEn News (Apr. 14, 2015, 6:01 PM), http://www.thanhniennews.com/society/old-habitinfamous-polluter-vedan-at-it-again-in-southern-vietnam-41107.html; Vedan Begins to Pay Compensation, Viet NAm News (Jan. 26, 2011, 8:45 AM), http://vietnamnews.vn/environment/207952/vedan-begins-to-pay-compensation.html\# ${ }_{22}$ DOutC5bQq2CvD1.97.

62 Alexandre Chitov, Environmental Considerations in Investment Law of Vietnam in the Context of Vedan Vietnam Case, 5 MFU Connexion Journal of Humanities and SoCIAL SCIENCES 1, 11 (2016). 
However, no criminal charges were brought against the polluter pursuant to the criminal code at that time. Vedan finally only had to pay over VND 200 million (approximately 16,00o USD) as a fine charged for its behavior of discharging untreated wastewater and the arrears of VND 120 billion (629 million USD) for backdated environment pollution fees. ${ }^{63}$ Along with such monetary punishments, Vedan Vietnam has to suspend its operations, dismantle the illegal drainage system within one month, and clean the environment within 6 months.

However, Vedan Vietnam had turned down the district's compensation requests and made meager counter-offers to affected farmers. In 2009, approximately 6,00o farmers filed lawsuits against the company as they did not accept Vedan's proposal. ${ }^{64}$ It was the first time a foreign company operating in Vietnam was sued for environmental pollution. ${ }^{65}$ The governmental agencies, particularly the Ministry of Natural Resources and Environment, were actively lobbying on behalf of the interests of farmers. The company then conducted individual compensation negotiations with the representatives of the farmers in each affected region. For example, in August 2010, "representatives from the Can Gio District Farmers Association in [Ho Chi Minh City] signed an agreement to postpone litigation on the condition that Vedan pays out $5^{\circ}$ percent of the sums promised[,]" which is VND 45.7 billion (US\$2.39 million) within a week. ${ }^{66}$

Farmers in the southern province of Ba Ria Vung Tau signed a similar agreement for VND 53.6 billion (US $\$ 2.8$ million) the same day, while the farmers in Dong Nai Province agreed to settle the case at nearly VND 120 billion $(\$ 6.29$ million) ${ }^{67}$ It was reported that Vedan had compensated the affected farmers altogether more than VND 200 billion (over $\$ 10$ million). ${ }^{68}$

63 Stephan Ortmann, Environmental Governance in Vietnam: Institutional REForms AND FAILURES 181-82 (2017).

64 Ninh Kieu, Vedan Lawsuit Warning for Other Foreign Firms Investors, Vietnam InvestMENT Review (Aug. 28, 2010, 4:38 PM), http://www.vir.com.vn/vedan-lawsuit-warningfor-other-foreign-firms-investors.html.

65 Id.

66 Farmers to Drop Lawsuits Following Vedan Payout Agreement, Than h Nien News (Aug. 14, 2010, 11:35 AM), http://www.thanhniennews.com/society/farmers-to-drop-lawsuitsfollowing-vedan-payout-agreement-15355.html.

$67 \quad I d$.

68 David Shepardson, VW Agrees to Pay \$20o Million into U.S. Pollution Reduction Fund, REUTERS (Dec. 17, 2016, 3:22 AM), http://www.reuters.com/article/us-volkswagen-emis sions/vw-agrees-to-pay-200-million-into-u-s-pollution-reduction-fund-idUSKBN1452Fo. 
The 2016 Vietnam marine life disaster was a water pollution crisis affecting Ha Tinh, Quang Binh, Quang Tri and Thua Thien-Hue provinces in central Vietnam. Formosa Ha Tinh Steel is a steel plant established in the Vung Ang Economic Zone, Vietnam by the Hung Nghiep Formosa Ha Tinh Steel Company under the backing of the Formosa Plastics Group of Taiwan. The steel plant of USD 22 billion is regarded as one of biggest FDI projects in Vietnam, recruiting about 10,000 workers in phase $1 .{ }^{69}$ The project enjoyed many investment incentives from the Government, including low "import taxes on machines, equipment[,] materials as well as ... taxation and land."70

In 2016, the Formosa Ha Tinh steel plant ("Formosa") discharged toxic industrial waste illegally into the ocean through drainage pipes. ${ }^{71}$ Fish carcasses were reported to have washed up on the beaches of Ha Tinh province from at least 6 April 2016. ${ }^{72}$ Later, a large number of dead fish were found on the coast of Ha Tinh and three other provinces (Quang Binh, Quang Tri and Thua ThienHue) until 18 April 2016. ${ }^{73}$ The Prime Minister claimed that the project of Formosa is the biggest investment ever in Vietnam but also causes the most severe pollution incident so far. $^{74}$

After denying responsibility for months, Formosa accepted responsibility for the fish deaths on 30 June $2016 .{ }^{75}$ Authorities estimate that seafood catches have fallen 1,6oo tons per month, according to the report. 140 tons of fish, 67 tons

69 Formosa Steel Lifts Investment to \$22b in Cast Iron Refinery, VIET. News (Apr. 24, 2012, 10:14 AM), http://vietnamnews.vn/Economy/223894/formosa-steel-lifts-investment-to-22b-incast-iron-refinery.html\#QzwzKqGZkFbFIZ9F.97.

70 Ministry Opposes Steel Region Plans, Viet. News (June 28, 2014, 10:49 AM), http:// vietnamnews.vn/economy/25678o/ministry-opposes-steel-region-plans. html\#J7VZCjiXrypDYUtF.99.

71 Vietnam Protest over Mystery Fish Deaths, BBC (May 1, 2016), http://www.bbc.com/news/ world-asia-36181575.

72 Ho Binh Minh, Vietnam, Grappling with Mass Fish Deaths, Clamps Down on Seafood Sales, REUTERS (Apr. 28, 2016, 4:26 PM), http://www.reuters.com/article/us-vietnam-formosaplastics-environment/vietnam-grappling-with-mass-fish-deaths-clamps-down-on-sea food-sales-idUSKCNoXPoQD.

73 Diep Pham \& Mai Ngoc Chau, Beaches of Dead Fish Test New Vietnam Government's Response, Bloomberg (May 2, 2016, 7:10 AM), https://www.bloomberg.com/news/articles/2016-05-01/beaches-full-of-dead-fish-test-new-vietnam-government-s-response.

74 Hải Quan, Thủ tướng Nguyễn Xuân Phúc: Nếu Formosa vi phạm trở lại sẽ đóng của nhà máy [Prime Minister Nguyen Xuan Phuc: To Close the Steel Plant If Formosa Violates Again], BÁOMớI.COM (July 24, 2017, 6:41 PM), http://www.baomoi.com/thu-tuong-nguyen-xuanphuc-neu-formosa-vi-pham-tro-lai-se-dong-cua-nha-may/c/22834093.epi.

75 Steve Mollman, A Taiwanese Steel Plant Caused Vietnam's Mass Fish Deaths: The GovernmentSays, QUARTZ (June 30, 2016), https://qz.com/718576/a-taiwanese-steel-plant-caused -vietnams-mass-fish-deaths-the-government-says/. 
of oysters and 16 tons of shrimp died as a result of the disaster. The toxic pollution caused by Formosa has hit at least 200,00o people by disrupting people's lives and destroying their livelihoods. The massive marine life destruction led to a number of protests by Vietnamese citizens in some cities on 1 May 2016, calling for a cleaner environment and demanding transparency in the investigation process.

On 30 June 2016, after two months facing the unrested wave of anger from the locals and pressure from the media, Formosa reached a settlement agreement in which Formosa agreed to pay VND 11.5 trillion (or \$500 million) in compensation to treat the pollution and mitigate consequences. ${ }^{76}$ On 29 September 2016, the Prime Ministerissued the Decision on the amount of compensation for the affected four regions' local citizens: "Ha Tinh, Quang Binh, Quang Tri and Thua Thien[,] Hue."77 Accordingly, there are 7 groups of industries hurt by the pollution incident, and the people working in these fields would receive the compensation determined by the Decision, in which each person is compensated at least VND 2.91 million per month and at maximum VND 39.37 million per month. ${ }^{78}$ Notably, pursuant to this Decision, the time to calculate damages runs from April 2016 until September 2016, which is no more than 6 months. ${ }^{79}$ Moreover, the payment by Formosa "covers only direct material damages, not psychological losses to fishermen whose income was severed." 80 Many affected people, however, were unhappy with the result of the settlement agreement as they wanted Formosa to close the steel plant and pay more compensation, as well as provide a better environmental cleanup.

III Analysis

Although the Formosa disaster happened 8 years after the Vedan pollution incident, they still share many common points which indicate that environmental dispute settlement in Vietnam has not been improved significantly.

76 Cần Văn Kình, Làm cá chết hàng loạt, Formosa bồi thường 500 triệu USD [Formosa Compensates 500 Million USD for Causing Massive Fish Death], Tuitre Online (June 30, 2016, 4:14 PM), http://tuoitre.vn/hop-bao-cong-bo-nguyen-nhan-ca-chet-o-mientrung-1127815.htm.

77 Thế Dũng, Formosa bồi thường người dân mức thấp nhất 2,91 triệu đồng/tháng [Formosa Compensates at Least 2.91 Million Dong per Month for Local Residents], NGườI LAO ĐộNG (Sept. 29, 2019, 10:18 PM), http://nld.com.vn/thoi-su-trong-nuoc/formosa-boi-thuongnguoi-dan-muc-thap-nhat-291-trieu-dong-thang-20160929215332338.htm.

$78 \quad$ Id.

79 Id.

8o Ralph Jennings, Vietnam's Solution to Fish Death Scandal Leaves Many Locals Unsatisfied, Forbes (Aug. 11, 2016, 10:30 PM), https://www.forbes.com/sites/ralphjennings/2016/o8/11/ why-mass-fish-kill-in-vietnam-still-smells-fishy-despite-a-solution/. 
First, regarding the discovery and investigation of violations, it is not clear whether any EIA procedure was complied with at the time of granting the investment certificate. In this respect, the legal provisions only attribute the competence to detail such provision, for example - the frequency and primary content of an EIAR, on the MONRE, without any further guidance or explanation on the standards or methods used in such a report. In practice, it is reported that in the 2005-2009 period, "[q]uantitative methods such as modeling, cost-benefit analysis and map convolution [methods] to specify impact scope are rarely used ... in EIAR in Vietnam." ${ }^{81}$ It was reported that: "the choice of model, parameters and input data is still [inappropriate, unreliable] and [lacks] scientific basis." ${ }^{2}$ Besides, there is a "lack of information and input data for EIAR process," ${ }^{83}$ as well as the limit of technical "equipment[] to verify EIAR results." ${ }^{\text {84 }}$ It was not until LEP 2014 that the Vietnamese legislature enacted a comprehensive rule of continuous environmental assessment for special areas along with the provision on EIAR. ${ }^{85}$ Nevertheless, the same problems may also be found in the execution of these tasks due to the lack of legal basis and proper guidance from the competent authority as mentioned above.

Second, most of the environmental disputes are resolved by way of negotiation and conciliation with the participation of the body in charge of State administration of the environment only. Regarding the process, residents in the affected area will first try to complain to the local governments, then engage in negotiations with the company to find a mutually acceptable solution. However, there are many questions unresolved regarding the transparency of this mechanism, in particular: (i) the procedures of environmental dispute mediation and negotiation, (ii) the procedure to elect the authorized representative for the stakeholders involved in such cases and his scope of authority, (iii) the calculation and types of damages, (iv) the assessment and categorization of the affected residents to be compensated, and (v) the plan to distribute compensation and clean up the pollution consequences. Furthermore, in the process of making a case for environmental courts which are mostly about the

81 Can Anh Tuan et al., Potential Uses of Environmental Impact Assessment Report for Environmental Dispute Resolution in Vietnam, 28 VNU Journal of SCIENCE, NATURAL ScIENCES AND TECHNOLOGY 64, 67 (2012).

$82 \quad I d$. at 68.

83 Id.

84 Id. at 70 .

85 LEP art. 65(3) provides that management boards of economic zones shall coordinate with state management agencies in charge of environmental protection in their localities in conducting environmental protection activities; and report on environmental protection in their economic zones in accordance with law. 
claim for compensation after the settlement is promised, it was acknowledged that "the initiation of lawsuits into court to claim for environmental damages is very difficult due to lack of legal basis." 86 In fact, although the local residents make claims about compensation for health problems as well as losses to their livelihood, it is difficult for the local People's Committees to assign blame, determine the victims and assess the cost of pollution. While the burden of proof does lie upon the plaintiff, the judge retains a general discretion to vary the distribution of the burden of proof in the requirements of justice in each case. ${ }^{87}$ Nevertheless, in any circumstance, this principle still imposes a heavy duty for such people who in the majority of cases originate from the socially and economically weak sectors of society and lack accessibility to evidence as well as technical knowledge of environment. ${ }^{88}$

Problems regarding ineffective approaches to environmental disputes may lie not only in the lack of expertise in dispute settlement and the inappropriate allocation of burden of proof, but also in the level of corruption amongst the government officials. In many cases, the local authorities are not even serious in sanctioning polluting companies. ${ }^{89}$ While such administrative agencies "are supposed to represent the demands of people, the local economy is much more important not only because it provides taxes and jobs but because the opportunities for promotion depend on reaching economic targets." ${ }^{90}$ Even though there are reports that some local governments refused to grant their approval to foreign investment projects after considering their impact on the environment, ${ }^{91}$ it is more likely that the financial flows from the investment projects will be treated with greater favor than unprofitable nature conservation projects. As one NGO country representative stated:

When you look at environmental issues in Viet Nam, you have to reali[z]e that it's only within the last ten years that environment even got on the agenda. Every country has problems[] and every country is trying to achieve economic growth. For most countries it is obvious how it will turn out environmentally and economically.... In Viet Nam it could go either

\footnotetext{
86 Ortmann, supra note 63 , at 114.

87 LEP arts. $165^{-66}$ (Viet.).

88 LEP art. 166 (Viet.).

89 Id.

90 Ortmann, supra note 63 , at 137.

91 Vu Xuan Nguyet Hong et al., Sustainable Development Impacts of Investment InCentives: A Case Study of the Mining Industry in Vietnam 7 (2009).
} 
way. They could become another 'tiger[,]' or they could fall off into some [other] kind of ecological disaster. ${ }^{92}$

Therefore, weak enforcement, lack of follow up on prosecution, and lack of technical capability especially in local government pose significant obstacles for enforcing environmental protection regulations and protection of the legitimate rights of aggrieved residents.

Third, news from media agencies only focuses on the happenings of the incident, ignoring the later stages of compensation and enforcement of the environment recovery measures. Meanwhile, the websites of competent governmental agencies do not regularly update the stages and timeline of the dispute after the settlement, which limits the accessibility of the stakeholders and other interested entities regarding the case. Together with the above-mentioned analysis, it is clear that the environmental dispute settlement mechanism in Vietnam does not fully satisfy any of the following important factors to effectively resolve environmental cases: (i) the independence of a environment dispute settlement mechanism, (ii) the flexibility and accessibility of such mechanism, (iii) the screening of cases suitable for mediation, (iv) the transparency of the dispute settlement process, and (v) the human resources of competent agencies.

Lastly, in both of these cases, the government threatened to "close" the projects if the violation of its environmental protection responsibilities by the MNCs continues. However, in fact, the government was not eager to exercise the State's police power in the public interests as it must ensure the measure taken complies with the "fair and equitable treatment" (FET) standard set under the IIAs. ${ }^{93}$ This standard is viewed as the main source of limitations to regulatory power in international investment law, which requires the examination of legitimate expectations of the investor and on the other hand, the good faith, transparency, fairness (by proportionality test), arbitrariness and discrimination of the measures conducted by the State to protect its public

92 Brent Doberstein, Environmental Capacity-Building in a Transitional Economy: The Emergence of EIA Capacity in Viet Nam, 21 Im PaCt Assessment And Project Appraisal 25, 29 (2003).

93 Benedict Kingsbury \& Stephan Schill, Investor-State Arbitration as Governance: Fair and Equitable Treatment, Proportionality and the Emerging Global Administrative Law 35 (N.Y. Univ. Sch. of Law Pub. Law \& Legal Theory Research Paper Series, Working Paper No. o9-46, 2009); Qinglin Zhang, On Public Interest in International Investment Agreements 21, http://dosya.marmara.edu.tr/huk/Sempozyumyay $\% \mathrm{C}_{4} \% \mathrm{~B}_{1}$ nlar $\% \mathrm{C}_{4} \% \mathrm{~B}_{1}$ / ipekyolucanlan\%C4\%Byor/Prof.Dr.QinglinZHANG.pdf. 
interests against the investor. ${ }^{94}$ Under the international investment law, the measure by the hosting state against the FDI that is tantamount to unlawful indirect expropriation may be subject to severe remedy. Given the weak environmental governance and institution in Vietnam, the application of strong penalties against one FDI may be easily found in non-compliance with the FED and national treatment requirements under the Vietnam-Taiwan вгт. Disputes Involving FDI in Vietnam

Attracting FDI for economic development and environmental protection are two of the most important components of the national social and economic development policy. Therefore, settling the environmental disputes involving FDI is not an easy task for Vietnam. The biggest challenge is how to balance FDI protection and environmental protection regimes that are mutually beneficial and supportive of each other. Based on the analyses above, it is suggested that Vietnam shall consider several solutions that follow.

\section{a Adopting the Reversed Burden of Proof in the Environmental Dispute Settlement Process}

From the cases studied, one of the main problems in the environmental disputes is that the claimants - people affected by industrial pollution, have limited expertise and financial resources to carry out the assessment and prepare the evidence against the foreign investor as required by the law.

To that end, a reversed burden of proof is suggested as a possible solution to the difficulties the claimants may face in an environment dispute. Pursuant to such a principle, the affected stakeholders do not have to prove the causation between the pollution or environmental incidents and their damages. Instead, the alleged polluter is obliged to provide evidence showing that they are not liable for such claims, or their liabilities could be mitigated in specific circumstances according to the law, or there is no causational link between the alleged violation and the damages at all. Such regulation has been adopted in China, providing that: "in compensation lawsuits concerning environmental pollution, the polluter carries the burden of proof with respect to demonstrating the lack of causal link between the polluter's actions and the

94 Dávid Rédli, Limitations to States' Regulatory Power in International Investment Arbitration Resulting from Standards of Protection, with a Focus on Fair and Equitable Treatment Standard 39-71 (May 30, 2016) (unpublished Master's thesis, Masaryk University). 
harmful result."95 To offer a more specific guide for such burden of proof, Article 6 of the Application of Law in the Trial of Liability for environmental Tort of China confirms that there is no causal connection in the following typical circumstances: (i) there is no possibility that the discharged pollutant could cause such damage, (ii) the discharged pollutants which could cause such damage have not arrived the place where the damages occurred, and (iii) the damages occurred before the discharge of pollutants. Thus, not only does this reversal of the burden of proof lighten the responsibility for the victims but it also shifts it to the party who has enough capacity, in both financial and technical aspects, to prove. Besides, in case of a force majeure incident, the alleged polluter is more accessible to its own source of evidence to prove the absence of a causal link between the alleged violation and the damage caused to the victims. Moreover, such a principle will urge the party seeking justice to file their claim to the dispute settlement bodies. The advantages of such an approach is illustrated by the Rongping case, where the judges in both trials correctly applied the doctrines of no-fault and reversal of burden of proof by stating that: "In accordance with the [']Supreme People's Court Certain Regulations Regarding Evidence in Civil Litigation['] in compensation litigation brought about by environmental pollution, the polluter has the burden to raise evidence to show the lack of causal connection between his behavior and the harmful result." ${ }^{96}$ Even though such provision on reversed burden of proof in China is praised as an ideal approach to resolving problems in environment dispute settlement, in practice, courts in this country are still known to require plaintiffs to produce evidence sufficient to demonstrate causation. ${ }^{97}$

In Vietnam, the call for a revision of the burden of proof in environment claims for compensation is not new, as it has arisen while the 2005 Law on Environmental Protection was still effective. Although the new law in 2014 has just revised the attribution of burden of proof in a more effective way, it still falls short of such an innovative reversal of the traditional burden of proof.

95 Zuigao Renmin Fayuan Guanyu Minshi Susong Zhengju De Ruogan Guiding (最高人民 法院矢于民事诉讼证据的若干规定) [Provisions of the Supreme People's Court on Evidence in Civil Procedures of People's Republic of China] (promulgated by the Sup. People's Ct., Dec. 21, 2001, effective Apr. 1, 2002), art. 4(3) (China).

96 Zhang Changjian et al. v. Pingnan Rongping Chem. Plant (Pingnan Interm. People's Ct. Apr. 2005); Zhang Changjian et al. v. Pingnan Rongping Chem. Plant (Fujian Provincial High People's Ct. Nov. 2005); see also Alex Wang, The Role of Law in Environmental Protection in China: Recent Developments, 8 Vermont Journal of Environmental LaW 195, 219 (2007).

97 Xu Kezhu \& Alex Wang, Recent Developments at the Center for Legal Assistance to Pollution Victims (CLAPV), 8 China Environment Series 103, 103-04 (2006). 
This suggested approach requires the governmental agencies' courage to comprehensively change its attitude toward innovative ideas and seriously implement such proposals in practice. Furthermore, in order to achieve the best justice and effective results in the application of such a principle, a reasonable allocation for burden of proof should be maintained. The legislative body must further elaborate on the evidence to be provided by each party. For example, the claimant is usually liable for providing evidence regarding the level of expected compensation, official health checks and other documents for this purpose in an environmental dispute. For the respondent's position, the certificate for environmental standard compliance, the scheme of a sewage system compliant to the EIAR or evidence of the presence of a force majeure incident, is required. Amongst those documents, the content of an EIAR, and/ or ESR is useful for the resolution of environmental disputes. The EIAR includes information about manufacturing and business activities, industrial wastes and data on the impacts on the natural resources and the environment. ${ }^{98}$ Furthermore, such assessment reports determine the scope and seriousness of the impact and damage caused to the environment, resources and community health, which is of significance in the process of environmental dispute resolution. The EIAR also defines the cost of performing environmental protection methods mentioned in the project implementation process, which also serves as a basis to calculate damages and indemnity costs. Meanwhile, the ESR specifies the environmental situation where the project is implemented or operated, methods to mitigate negative environmental impacts, the results and the commitments of the project owners. Amongst other benefits, most of all, the appraisal of the EIAR/ESR means that the information and data contained in such reports is legalized. Therefore, the EIAR and ESR could be used as one piece of important evidence provided by the respondent to a neutral third party to consider his responsibility. Considering such reports together in the process of environmental dispute resolution will better enhance the accuracy, transparency and justice of the settlement outcome. To ensure the effective use of the reports, a unified system for EIAR and ESR needs to be improved, along with the well-specified guidance on mandatory use of methods and calculation software for quantitative assessment of the scope and extent of environment impacts. ${ }^{99}$ National and industry input information database for EIAR and ESR needs to be built systematically and under the control of specialized authorities such as the MONRE and the DORE.

98 Tuan et al., supra note 81 , at 69 .

$99 \quad I d$. at 71. 


\section{b Establishing the Mediation Center for Environmental Disputes}

According to the practice of environment dispute settlement in Vietnam, it is crucial to introduce a proper alternative dispute resolution (ADR) approach to assist courts in resolving environmental disputes. Amongst which, mediation seems to be the most feasible and appropriate means of environmental dispute settlement. Some insist mediation is not suitable when it comes to such kind of disputes, as the conflicts involve public issues that must be resolved by the court. ${ }^{100}$ Besides, "others claim environmental ADR [including mediation] is useful only in limited circumstances"101 as such disputes often "provoke sharp disagreements, or serious uncertainties about predicting the long-term efficacy of settlements" (such as issues regarding the assessment of cleanup remedy effectiveness), which should be excluded.102 Moreover, mediation results are not binding as judicial awards, so it always "carries the risk that disgruntled parties will refuse to enter into a settlement."103

Nevertheless, it is undeniable that the use of mediation in environmental disputes cites many advantages. First, while an environmental lawsuit may be rigid and time-consuming, mediation may offer a quicker resolution for the dispute. Second, "[e]nvironmental disputes are often complex cases involving multiple parties, complicated statutes and regulations, and reams of scientific and technical evidence.... The typical environmental dispute is dynamic, as new issues tend to arise throughout the life of the dispute and the cast of parties changes continually." ${ }^{104}$ Hence, this kind of dispute needs flexible means of dispute resolution to effectively assist parties involved in such a byzantine situation, particularly mediation, in which the participants themselves decide what the process will be and what form of dispute settlement will be most appropriate. Given such preferable flexibility, mediation can encourage "settlements

100 Amy, supra note 46; Edward Brunet, Questioning the Quality of Alternative Dispute Resolution, 62 Tulane LaW Review 1, 17-18 (1987), in Federal Administrative Dispute Resolution Deskbook for Practitioners 372-73 (Marshall J. Breger et al. eds., 2000).

101 Joel B. Eisen, Alternative Dispute Resolution at the Environmental Protection Agency, in Federal Administrative Dispute Resolution Deskbook for Practitioners 373 (Marshall J. Breger et al. eds., 2000).

102 Allan R. Talbot, Settling Things: Six Case Studies in Environmental Mediation 91 (1983), in Federal Administrative Dispute Resolution Deskbook for Practitioners 373 (Marshall J. Breger et al. eds., 2000).

103 Stephanie Pullen Brown, Alternative Dispute Resolution: An Alternative to Superfund Litigation, http://www.pipermar.com/articlelO.html (last visited Oct. 10, 2017), in FEDERAL Administrative Dispute Resolution Deskbook for Practitioners 373 (Marshall J. Breger et al. eds., 2000).

104 Eisen, supra note 101, at 371-72. 
that go beyond mere recovery of costs or imposition of monetary penalties, and maximize opportunities for improvements to environmental quality ... as part of settlements." 105 Moreover, while litigation admits the existence of the dispute and may be too adversarial and clear-cut, which may render the participation of both parties in the settlement impossible, mediation may help preserve relationships between parties and provide communication environment for parties to restore mutual trust. ${ }^{106}$ Therefore, it is easily found that many countries adopt ADR, especially mediation, as an effective means to resolve environmental disputes.

First and foremost, the independence of such committee should be ensured by the establishment of a separated administrative mediation mechanism, for example, the Committee for Environmental Dispute Settlement Cooperation (EDSC Committee). This organization should be under administrative control of the MONRE, in particular, the Head of the committee should be appointed by the Minister of the MONRE. This requirement could preserve the neutrality of the Committee when a party involved in the environmental dispute is the investor whose project is ratified by the Prime Minister or the Chairman of the People's Committee. Such an approach has also been adopted in the USA and Japan, which are countries with enormous experiences in environmental protection legislation. ${ }^{107}$

105 Id. at 372 .

106 Id.

107 United States Environmental Protection Agency (EPA), Journal of REgulation, http:// thejournalofregulation.com/en/article/united-states-environmental-protection-agency -epah/ (last visited Oct. 10, 2017) ("The United States Environmental Protection Agency (EPA or sometimes USEPA) is an agency of the federal government of the United States which was created for the purpose of protecting human health and the environment by writing and enforcing regulations based on laws passed by Congress."). The Head of the EPA is the Administrator who is accorded Cabinet rank. The Conflict Prevention and Resolution Center (CPRC) is the EPA's primary resource for services and expertise in the areas of consensus-building, collaborative problem solving, alternative dispute resolution, and environmental conflict resolution. See Conflict Prevention and Resolution Center: About the CPRC, U.S. EnVtL. Protection Agency, https://www.epa.gov/adr/aboutcprc (last visited Oct. 10, 2017).

Japan has been focusing on the development of administrative ADR to resolve environmental disputes instead of resorting to judicial system. Aya Yasui, Alternative Dispute Resolution System in JAPAN 1, http://www.iadcmeetings.mobi/assets/1/7/ 18.2_-_Yasui-_ADR_System_in_Japan.pdf (last visited Oct. 10, 2017) ("By 1940, other mediation systems such as tenant farmer (peasant) mediation, labor dispute mediation, commercial mediation, personal status (family) mediation and environmental compensation mediation have been implemented in Japan."). The Environmental Dispute Coordination Commission of Japan was established in 1972 as an external agency of the Prime Minister's Office, by consolidating the Land Coordination Commission and the Central Pollution 
The main function of the EDSC Committee is to resolve environmental disputes promptly and appropriately through ADR means, as the research activities and other duties are taken by the MONRE. An administrative mediation mechanism should be adopted by the Committee as the disputing parties may enjoy the benefit of a simplified, flexible and speedy closed-door proceeding, while the public interests are preserved with the administrative observation. The Committee's full-time personnel should be selected from the Ministry and from different background such as engineers, scientists, legal, public affairs, financial experts, and information technologists in order to effectively solve various complex issues arisen from an environmental dispute. The EDSC Committee may also engage its staff on a contractual basis in case the situation requires more people to be involved. Furthermore, to assist people quickly in environmental issues, the Committee's offices should be located in three major cities in Vietnam including Ha Noi, Da Nang and Ho Chi Minh City and other provinces undergoing industrialization.

Second, in such severe environmental disputes such as that of Formosa Steel or Vedan, an ad hoc mediation committee should be composed to rapidly ease public disorder and settle the post-settlement ADR procedures, especially issues concerning the damages, compensation and clean-up remedies. The ad hoc mediation committees in Japan are the ideal models to follow. The most well-known dispute handled through mediation is the Minamata case, where a fatal disease first identified in the late 195 os was traced to the eating of shellfish

Examination Commission. The Commission consists of one President and six members, together executing the mission to provide mediation, conciliation, arbitration and adjudication services to resolve environmental disputes quickly and justly amongst other tasks. Paying for Pollution: Environmental Mediation in Japan, The Alicia Patterson FounDATION, https://aliciapatterson.org/stories/paying-pollution-environmental-mediationjapan (last visited Oct. 10, 2017) ("Headed by a chairman of Cabinet rank, the commission mediates dozens of major disputes between industrial enterprises and persons whose health or property has been injured by hazardous wastes."). Its success is recorded in the annual report, in particular, from April 1, 2014 to March 31, 2015, 74,785 complaints have been received by local governments. See Environmental Dispute Coordination Commission, Characteristics of the System for Settling Environmental Disputes, http://www.soumu. go.jp/kouchoi/english/settlement/charact.html (last visited Oct. 10, 2017); see Environmental Dispute Coordination Commission, Environmental Pollution Complaints, http:// www.soumu.go.jp/kouchoi/english/settlement/comp.html (last visited Oct. 10, 2017) [hereinafter Environmental Dispute Coordination Commission, Complaints]; see also Environmental Dispute Coordination Commission: Activities, Prime Minister of JAPAN AND His CABInET, http://japan.kantei.go.jp/syoukai_e/e_html/kogai/o1.html; Pollution Complaints Consultation and Pollution Dispute Processing, Ministry of InTERnAL AFF. AND Coмm., http://www.soumu.go.jp/kouchoi/menu/main7dispute.html. 
in Minamata Bay which was contaminated by the mercury compound discharge from a fertilizer plant named Chisso. ${ }^{108}$ In this case, the Governor Teramoto established an ad hoc mediation committee called the "[C]ommittee on Mediation for Fishery Disputes in the Shiranui Sea on November 24, 1959, and started mediating the disputes." 109 The committee's role was to help determine the size of the compensation for the "official victims," as well as to control the Minamata disease affair as an orderly affair. On December 30, 1959, a mediation draft on compensations for patients was agreed to and signed between the representative of Minamata Disease Patient's Families Mutual Aid Society and Chisso. ${ }^{110}$ Furthermore, the Japanese government in April 2011 established the Dispute Reconciliation Council for Nuclear Damage Compensation (Genshiryoku Songai Baisho Funso Shinsa-kai; "Reconciliation Council") in the Ministry of Education, Culture, Sports, Science and Technology in order to ensure proper and efficient compensation for those victims afflicted by the release of radioactive substances in the power plant accident in Fukushima in March 2011. ${ }^{111}$ The Japanese government also established the Nuclear Damage Compensation Dispute Resolution Center ("Nuclear Damage ADR Center") under the Reconciliation Council to deal with an exceptionally high number of claims arising from the accident. ${ }^{12}$ Learning from Japan, how such an ad hoc committee is established in Vietnam to resolve environment disputes is within the authority of the EDSC Committee and should be regulated with transparent regulations. This ad hoc committee would be staffed by part-time mediators and assistants appointed by the EDSC Committee.

Besides, the screening of cases suitable to be resolved by mediation is also of significance and should be regulated as the first stage of a mediation process. There are two methods to categorize environmental disputes to be mediated, consisting of: (i) the categorization based on the scale, and (ii) the categorization based on the content of a dispute. The first approach was taken by Japan where its National-level Environmental Dispute Coordination Commission handles environmental grave cases, cases with nation-wide implications, and inter-prefectural cases, while the Prefectural Commissions have competence

\footnotetext{
108 Nat'l Inst. for Minamata Disease, in the Hope of Avoiding Repetition of the Tragedy of Minamata Disease: What We Have Learned from the ExpeRIENCE 1-2 (2001), http://nimd.env.go.jp/syakai/webversion/pdfversion/e_houkokusho. pdf.

109 Id. at 43.

$110 \quad I d$. at 52.

111 YASUI, supra note 107 , at 2.

112 Id.
} 
on cases that do not fall under the jurisdiction of the Commission. ${ }^{113}$ Along with other factors, such an effective structure of organization helps resolve 90 percent of environmental claims in Japan. ${ }^{114}$ Regarding the second method of categorization, the Environment Protection Agency of the USA adopts such an approach by creating a list of factors to select a suitable case for environment, including the feasibility in the negotiation regarding time and cost, the negotiable possibilities, the information to substantiate the violations, and the statute of limitations. ${ }^{115}$ The Committee in Vietnam should take both approaches and organize its structure to handle cases with different scales and nature, such as the Ministry-level Committee to resolve grave and inter-provincial cases and local Committees to address other cases.

Third, another important issue to be considered is the confidentiality/ transparency of environment mediation. Although mediators may argue that the confidential nature of their relationships with the disputants is critical to their success, the content of the dispute may relate to the human health, environment management and recovery costs as well as other consequences which pose negative effects on the public interests of stakeholders who are not directly involved in the mediation process. ${ }^{116}$ Therefore, all stages concerning the settlement of disputes (both pre and post-mediation) and enforcement should be updated continuously in the media, such as on the website of the EDSC Committee or the MONRE, to ensure the transparency, accessibility, and justice of the proceedings. Moreover, the dispute parties and the mediation committee can consider and agree on the publishing of some documents such as records generated in the mediation process which may be potential evidence for future litigation, content of the mediation settlement, and facts of the dispute. ${ }^{117}$

Adopting the Corporate Social Responsibility Clause in the BITs and RTAS

In order to facilitate the flow of international investment while minimizing the negative side of FDI, it is necessary to condition the relationship between interested parties. Corporate Social Responsibility (CSR) is defined as a way in which enterprises give consideration to the impact of their operations on society,

\footnotetext{
113 Environmental Dispute Coordination Commission, Complaints, supra note 107.

114 Id.

115 The Alternative Dispute Resolution Fact Sheet, https://quicksilver.epa.gov/work/05/275605. pdf.

116 Eric R. Max, Confidentiality in Environmental Mediation, 2 New York University ENVIRONMENTAL LAW JouRnal 210, 211 (1993).

117 See Taylor et al., supra note 48 , at $82-85$.
} 
aiming for best practice and experimentation with new technologies and innovative approaches. ${ }^{118}$ It is a voluntary, enterprise-driven initiative encouraging activities beyond the compliance with the law. ${ }^{119}$ In Vietnam, most multinational companies implement these programs, contributing to improvement in the business environment. ${ }^{120}$ Noticeably, not only is it popular amongst foreign companies, the awareness of CSR programs is also increasing in domestic enterprises, though mostly adopted by the largest Vietnamese companies. ${ }^{121}$ In the context where there is a trade-off between environment protection and FDI attraction, in order to promote these programs amongst investors as well as to give them a certain standing, the inclusion of CSR in bilateral and regional trade agreements (RTAS) should be considered as a significant factor in policymaking. The absence of a requirement to go beyond enforcement of domestic provisions may indeed lead to trading partners' escaping responsibility sooner than their incurring it.

In such agreements, CSR should include both compliance and voluntarism, underlying the significance of voluntary approaches backed by mandatory requirements. To be more specific, the crucial aspect of CSR is that "it encourages companies to not only serve the traditional needs of shareholders, but also the needs of other stakeholders, including civil society groups, community leaders, customers, employees, government entities, international organizations, media, suppliers, trade unions, trustees, and future generations."122 Although in some stages, the interests of stakeholders and companies confront each other, they are in fact closely connected and mutually dependent. For instance, 61 percent of FDI companies in Vietnam state that building good reputation and image amongst customers is the most significant driving force to urge their compliance with environment protection regulations. ${ }^{123}$ In return, the FDI projects create jobs, improve infrastructure in industrializing areas which benefit the locals and help the government achieve its goal in the macro economic context.

118 Rafael Peels et al., Corporate Social Responsibility in International Trade and Investment Agreements: Implications for States, Businesses, and Workers (ILO Research Paper No. 13, 2016), http://www.ilo.org/wcmsp5/groups/public/---dgreports/---inst/documents/publi cation/wcms_476193.pdf.

119 Id. at 6.

1202016 Investment Climate Statements, U.S. Dep'T OF ST., http://www.state.gov/e/eb/rls/ othr/ics/2016/eap/254329.htm (last visited Oct. 10, 2017).

121 Id.

122 UNEP, Corporate Social Responsibility and Regional Trade and InvestMENT AgreEments 13 (2011), http://unep.ch/etb/publications/CSR\%2opublication/ UNEP_Corporate\%2oSocial\%2oResponsibility.pdf.

123 Dinh, supra note 37, at 48. 
Hence, by adopting CSR clauses in the BITs and RTAs, this provision should not only impose responsibilities upon the investing corporations, but also provide regular consultation on CSR issues between the governments party to an agreement and stakeholder groups, between the stakeholder groups and FDI companies and between the governments and FDI companies before an investment decision is made and during the business' performance. It allows company executives and stakeholders to address social or environmental concerns before the problems become serious, and to help government and FDI companies have a better understanding of their rights and obligations imposed by CSR provisions. Besides, the government may provide funding for companies that become certified to particular CSR standards or facilitate their research about new and environment-friendly technology.

Therefore, in order to prevent environmental conflicts as well as to effectively resolve any environmental dispute involving foreign investors, Vietnam should fully understand its limitations in the exercise of State police power regarding environment protection and, on the other hand, adopt CSR provisions in the BITs and RTAs to which it is a party. Such provisions may be adopted from that of the Canada-Peru agreement, which is a typical example that references CSR in both the preamble and in several chapters of the body of the Agreement. For instance, in the Preamble of the agreement, both Canada and Peru agree to:

Encourage enterprises operating within their territory or subject to their jurisdiction, to respect internationally recognized corporate social responsibility standards and principles and pursue best practices. ${ }^{124}$

Furthermore, the investment section of the Canada-Peru agreement includes a special section even named "Corporate Social Responsibility":

Each Party should encourage enterprises operating within its territory or subject to its jurisdiction to voluntarily incorporate internationally recognized standards of corporate social responsibility in their internal policies, such as statements of principle that have been endorsed or are supported by the Parties. These principles address issues such as labor, the environment, human rights, community relations and anti-corruption. The Parties, therefore, remind those enterprises of the importance of

124 Canada-Peru Free Trade Agreement, Can.-Peru, Preamble, May 28, 2008, https://www. international.gc.ca/trade-commerce/trade-agreements-accords-commerciaux/agr-acc/ peru-perou/fta-ale/index.aspx?lang=eng (entered into force Aug. 1, 2009). 
incorporating such corporate social responsibility standards in their internal policies. ${ }^{125}$

The Canada-Peru agreement also creates an institutional mechanism to, inter alia, promote cooperation on CSR as a formal forum. ${ }^{126}$ This action initiated by Canada and Peru is not a single case, but it is followed by the good practice found in the Netherlands - where its Centre for the Promotion of Imports from developing countries (CBI) provides training to exporters from developing countries on social and environmental issues. It is easy to see that the governments of these countries have soon realized CsR is one of the effective solutions for negative effects of FDI in such robust international commerce contexts. In short, by providing CSR clauses directly in the investment and trade agreements, the parties are encouraged to be responsible for environmental preservation and social welfare as well as to cooperate effectively and harmoniously.

\section{Conclusion}

In order to enhance environmental protection activities and achieve many tasks at the same time, Vietnam's environmental laws are ambitious and becoming more detailed to catch up with the changes of society. However, they are at times contradictory as they conflict with other laws and regulations on the responsibilities of the investor regarding environment protection. The inefficiency of State governance for environmental issues also poses another challenge. Furthermore, the lack of appropriate concern about the sustainable development objectives in BITs is considered to affect not only the business environment and the effort to attract investments in Vietnam, but also the State's regulatory capacity to pursue public interest needs through legitimate policies in the fields of health, environment, security, etc. These shortcomings are proved to be the source of increasing and unresolved environmental disputes in practice. Hence, it is imperative for Vietnam to settle the issue in such manner that can maintain the status of an "FDI friendly" country and at the same time reasonably protect human and animal health, as well as the environment.

The government shall design a good policy and also a good plan on how to overcome the challenges. The solutions must be taken in various aspects, especially the restructuring of an environmental dispute settlement system. It is

125 Id. art. 810.

126 Id. art. 817. 
important to help the victims of the industrial pollution by easing their burden of proof in environmental disputes by shifting this responsibility to the investor. The flexible and independent ADR with the supports of administrative authorities should be encouraged for settlement of environmental disputes with FDI. Lastly, foreign investors should be encouraged to voluntarily contribute to the protection as well as the cleaning up of the environment. Thus, it is advisable to ensure adoption of Corporate Social Responsibility provisions in Vietnam's future BITS and RTAS. 